\title{
The Application of Modern Art in Urban and Rural Planning
}

\author{
Chongzhou Fei ${ }^{1,}$, , Liang Yan ${ }^{1,}$ b \\ ${ }^{1}$ School of Architecture and Urban-Rural Planning, Sichuan Agricultural University, Chengdu \\ 611830, China. \\ a79434920@qq.com, b51027540@qq.com
}

\begin{abstract}
With Chinese modern art winning higher status in and outside China, the group, consisting of artists, architects, and planners, pay more attention to the development and reconstruction of Chinese urban and rural space. Based on current overseas studies related to art and city, this essay discusses six patterns in using Chinese modern art in urban and rural space, exemplified with cases in Chinese urban and rural planning and construction: diversity and difference pattern in applying art in city village; cultural and business pattern in applying art in the transformation of industrial cities and old workshops; taste and symbolic cultural pattern in intervening real estate projects and urban complex; mass consumption pattern in applying art in tourist towns; government supported pattern in cultural creative industrial parks; instant exploding pattern in urban annual art exhibitions.
\end{abstract}

Keywords: Modern art, city village, industrial heritage, annual art exhibition, cultural creative industrial park.

\section{Introduction}

With development of the country and the transformation of society, art and culture are playing a more and more important role in influencing the society. Meanwhile, the public and government take part with enthusiasm and fund, which encourages the development of cultural creative industry. In other words, it is a global trend to apply arts in the development of urban and rural areas. The Application of Art (in broad sense) means that the artists practical interfere through art exhibitions, projects and works, aiming at influencing the local residence, relative community, governments and the reform of urban-rural dualism. From 1960s, with the development of "conceptual art" and "modern art" and professional exhibition, art become part of the society and the public, which leads to the expanding of the artists' practice and application of arts The group taking part in applying art in cities and countryside consist of geographers, artists, architects, IT technicians in new media, scientists, philosophers, literary critics, real estate developers, international organizations, governments, various foundations, etc. pay more attention to the development and reconstruction of Chinese urban and rural space. For instance, Shenzhen- Honking Bi- city Biennale of Urbanism/ Architecture in 2013 includes various fields, like industrial heritage, urban planning, architectural design, public participation, artistic interference, etc.

This essay focuses on the practices of applying art in urban and rural planning. Based on relative current studies and cases, it discusses basic patterns in using Chinese modern art in urban and rural space, trying to discover the potential of applying modern arts in planning.

\section{The Application of Modern Art in Urban and Rural Planning and Current Studies}

There are many studies on applying art in urban and rural space development, from the perspective of art, urban studies, geography, etc. However, very little studies presents comprehensive introduction. Current studies can be put into four categories:

(1) Study on gentrification and renewal of cities

(2) Study on cultural economy and creative cities

(3) Study on public art and community art

(4) Study on new art geography and creative geography

Comparing relative studies in and outside China, little evidence of cross-discipline communication can be found among those studies. In spite of that, some studies tend to the application of applying 
art in urban and rural space in China with practices and cases, which demonstrates an increasing trend. For instance, the previous "Old Summer Palace Painters' Village" and "East Village Behavior Art", and the more recent "798" Art Park, "Song Village", "Red Square" in Shanghai, Shenzhen OCAT Creative Park, Predatory in Guangzhou, White Horse Lake in Hangzhou, Deafen Oil Painting Village, etc. All of them demonstrate that art, artists and cultural and cultural creators are intervening the reconstruction and application in city centers, suburbs, old industrial districts and other urban space.

Moreover, artistic real estate flourishing in recent years, Drama Hall, Art Gallery, Museum, Luxurious cinema, all presents the application in city center, cultural tourist area, urban business center (CBD), and residence. The application of art in first-tier cities has now expanded to secondtier, third-tier middle cities and small cities, even to the decaying rural areas. For example, by holding international photography festival, some city tries to win international reputation and dynamics and opportunities in urban-rural development.

\section{The Patterns of Using Modern Art in Urban and Rural Planning}

The application of modern art in urban and rural planning is conducted by the practice of artists in general sense and some relatively independent art, which is also supported by local government with human resources, material resources, and policy. When it comes to the case study in China, the whole mode, policy making and social influence, the previous studies indicate great gap in research. This essay is based on observation of practical projects, relative study, and news reports and so on, trying to make a conclusion of six patterns in the application of modern art in urban and rural.

\subsection{Applying Art in City Village-Multi-Dimension and Difference Pattern}

Modern artists and scholars have been studying city village for a long time. For example, there were a lot of young artists gathering in Old Summer Palace Painters' Village. Although this particular village has disappeared, more and more "Painters' Villages" is springing up. In the suburbs of Beijing, Song Village attracts many artists, artistic youth, art fans, and even migrant workers. It is also the case in Xiao Zhou Village in Guangzhou and Deafen Village in Shenzhen. Most of the work on activities related to art, influencing life in the community unprecedentedly-some refreshes the local space, some puzzles the residents - whatever the way is, the driving effect on culture and economy in local city villages is very obvious. When artists apply art in the way of their existence, it often leads to differences, which is the result of the different location of different city village in different city, the gathering and ways of activities of artists, regulations related to local government and divisions, etc.

\subsection{Applying Arts in the Transformation of Old Industrial Cities and Old Workshops-- Cultural and Business Pattern Based on Industrial Heritage}

Old industrial cities and old workshops is another important place for the artists to get together and express their passion in art, which related to the typical cases in reserving and transformation of old workshops, and also the transmission of the notion on industrial heritage from overseas[1]. Beijing "798" is the most successful pioneer case in transforming old workshops to cultural art zone, which represents the transformation of state-owned entrepreneur and breakthrough of state-owned property. When the workshops is no longer used for industrial production, they required emptying out and renting, which is the original chance and fundamental cause of the born of Beijing 798. No matter 798 or Suzhou River, these tall and wide workshops have reinvented themselves to be the most important and fashionable art districts and cultural creative parks in Beijing and Shanghai. They have been more and more commercialized. When art shop can always afford much more rent than artists, designers' workshops and exhibition space [2], "loft" style becomes very popular.

\subsection{Applying Art in Real Estate Projects and Urban Complex--Art and Asset Pattern}

Real estate developers have been playing a vital role in urbanization in China. They are also very important in the practice of the application of art, although their interference seems to be slow, and 
received a lot critic from artist at the early stage, for destroying the spontaneous urban culture and art and citizens' living space. However, when "One thousand city, one building" was criticized and the notion of cultural confidence and art city sprung up, some real estate developers noticed the importance of art in urban planning: they build cultural art space in the recent planned residence and community, and business complex, providing space for better communication among people. What is more, some real estate developers, like Mr. Wang Jialing from Wanda, take part in collecting art works. To what extent can art be applied in living space and urban business complex requires further observation and study.

\subsection{Applying Arts in Planning Tourist Towns-- Mass Consumption Pattern}

In China, the outlook of modern art and its business potential are closely connected to the "mass" group. For example, ordinary people, artistic youth and other art fans and consumers would gather in certain small towns like Jiangmen Region, Lijiang, Gulangyu Island, etc. Modern art is vital for the construction in new-style urbanization in middle-size and small towns and villages.

\subsection{Applying Art in Planning Cultural Creative Industrial Parks--Government Supported Pattern}

Industrial park, Development Park, and high-tech zone are the milestones in industrialization and urbanization. Cultural creative industrial park is another glorious one. After taking in, learning, and absorbing the development of creative city and cultural industry from the other countries, Chinese government put forward a new mode of urban space planning, in the progress of urban and rural transformation and update.

\subsection{Applying in Annual Modern Art Exhibitions in Urban Planning--Instant Exploding Pattern}

Cultural creative parks have a great influence on city village, some old industrial zones worth reserving and the shift to third industry. Moreover, a recent trend of holding art festivals, especially annual exhibitions, is also noticeable. Art festivals and annual exhibitions lure artists from the west and east, young scholars, relative media, and art fans, who gather and discuss issues related to art and city. This is a typical pattern of interference by using the art exhibitions. Although the mode presents instantaneity and temporality, it draws the attention of social members and encourages their practices, which prepare a good environment for further application of art.

\section{Conclusion}

Art has been applied in cities for a long time. However, before reform and open-up, or even before cultural industry became national strategy, art like painting, sculpture, and music only exist in the city as part of cultural and educational infrastructure, serving the socialist construction and national politics. The influence was usually static, no matter from the art gallery and museum in big cities, or from stages and open cinema in middle/small cities and small towns. Looking back to the development in recent years, the application of art in China's urban and rural construction has gradually become a kind of productivity, consumption ability, and distribution ability. Application of art has been freed from constrains of national regulations. Artists, exhibition planners, international cultural organizations, domestic and foreign assets, real estate developers, urban planning and construction, media, and so on, they have all influenced the way art exist and being applied in the city.

\section{References}

[1]. Li Leila. De-industrialization and development of industrial heritage tourism: the actual process and development model of Ruhr in Germany. World Regional Studies. 2002, 11(3): 57-65. 
[2]. Wu Di. Creative 798: No.1-Interviewing 13 creative shops in 798 Art Zone. Changchun: Jilin Fine Art Press. 2010. 1-57. 